https://helda.helsinki.fi

\title{
The origin of mouth-exhaled ammonia
}

\section{Chen, W.}

2014-09

Chen , W , Metsala , M , Vaittinen , O \& Halonen , L 2014 , ' The origin of mouth-exhaled

ammonia ' , Journal of Breath Research , vol. 8 , no. 3 , 036003 . https://doi.org/10.1088/1752-7155/8/3/036003

http://hdl.handle.net/10138/152832

https://doi.org/10.1088/1752-7155/8/3/036003

acceptedVersion

Downloaded from Helda, University of Helsinki institutional repository.

This is an electronic reprint of the original article.

This reprint may differ from the original in pagination and typographic detail.

Please cite the original version. 


\title{
The origin of mouth-exhaled ammonia
}

\author{
W Chen, M Metsälä, O Vaittinen and L Halonen \\ Laboratory of Physical Chemistry, Department of Chemistry, PO Box 55 (A.I. \\ Virtasen aukio 1), FIN-00014 University of Helsinki, Finland \\ E-mail: markus.metsala@helsinki.fi
}

\begin{abstract}
It is known that the oral cavity is a production site for mouth-exhaled $\mathrm{NH}_{3}$. However, the mechanism of $\mathrm{NH}_{3}$ production in the oral cavity has been unclear. Since bacterial urease in the oral cavity has been found to produce ammonia from oral fluid urea, we hypothesize that oral fluid urea is the origin of mouth-exhaled $\mathrm{NH}_{3}$. Our results show that under certain conditions a strong correlation exists between oral fluid urea and oral fluid ammonia $\left(\mathrm{NH}_{4}{ }^{+}+\mathrm{NH}_{3}\right)\left(r_{s}=0.77, p<0.001\right)$. We also observe a strong correlation between oral fluid $\mathrm{NH}_{3}$ and mouth-exhaled $\mathrm{NH}_{3}\left(r_{s}=0.81, p<0.001\right)$. We conclude that three main factors affect the mouth-exhaled $\mathrm{NH}_{3}$ concentration: urea concentration, urease activity and oral fluid $\mathrm{pH}$. Bacterial urease catalyses the hydrolysis of oral fluid urea to ammonia $\left(\mathrm{NH}_{4}{ }^{+}+\mathrm{NH}_{3}\right)$. Oral fluid ammonia $\left(\mathrm{NH}_{4}{ }^{+}+\mathrm{NH}_{3}\right)$ and $\mathrm{pH}$ determine the concentration of oral fluid $\mathrm{NH}_{3}$, which evaporates from oral fluid into gas phase and turns to mouth-exhaled $\mathrm{NH}_{3}$.
\end{abstract}

\section{Introduction}

Ammonia in the human body originates mainly from the metabolism of diet protein and is converted to urea in the liver [1]. The average $\mathrm{pK}_{\mathrm{a}}$ value of ammonia in blood and water is 8.95 at $37{ }^{\circ} \mathrm{C}$ [2], which is higher than the $\mathrm{pH}$ value of physiological fluids, ranging from 4.5 to 8.0 [3]. Hence, ammonia is present mostly in the ammonium ion $\left(\mathrm{NH}_{4}{ }^{+}\right)$form, and only a small fraction is in the ammonia molecule $\left(\mathrm{NH}_{3}\right)$ form. In this text, we use ammonia as a general term to represent both forms $\left(\mathrm{NH}_{4}{ }^{+}+\mathrm{NH}_{3}\right)$, except for further notification. The normal blood ammonia concentration is 11-50 $\mu \mathrm{mol} / \mathrm{L}[4]$. Since ammonia passively diffuses from blood to both salivary and sweat glands, it can be detected in oral fluid and sweat $[5,6]$. In addition to body fluids, $\mathrm{NH}_{3}$ has been detected in exhaled breath using various methods, including selected ion flow tube mass spectrometry [7], ion mobility spectrometry [8], cavity ring-down spectroscopy [9], and photoacoustic spectroscopy [10].

In some previous studies, a positive correlation was observed between plasma $\mathrm{NH}_{4}{ }^{+}$and mouthexhaled $\mathrm{NH}_{3}$ in patients with hepatic diseases [11,12]. Given such results, a logical conclusion would be that mouth-exhaled $\mathrm{NH}_{3}$ originates from blood ammonia, based on the gas exchange between blood and the air in the alveoli $[13,14]$. However, recent studies found no correlation between plasma $\mathrm{NH}_{4}^{+}$ and mouth-exhaled $\mathrm{NH}_{3}$ in either hepatic disease patients or healthy people [9,15]. Therefore, it is unclear whether mouth-exhaled $\mathrm{NH}_{3}$ reflects the systemic ammonia level directly. It has been proven that the mouth-exhaled $\mathrm{NH}_{3}$ concentration is higher than the nose-exhaled $\mathrm{NH}_{3}$ concentration $[9,16-$ 18], indicating that in addition from the alveoli, mouth-exhaled $\mathrm{NH}_{3}$ also originates from the oral cavity. Smith et al further demonstrated that the $\mathrm{NH}_{3}$ concentration in the oral cavity during breath 
holding is correlated to the mouth-exhaled $\mathrm{NH}_{3}$ concentration [17], implying that mouth-exhaled $\mathrm{NH}_{3}$ is dominantly generated in the oral cavity.

Exhaled breath $\mathrm{NH}_{3}$ has been proposed as a non-invasive biomarker in several different clinical applications. It has been found that mouth-exhaled $\mathrm{NH}_{3}$ is statistically significantly correlated to blood urea in chronic kidney disease patients during haemodialysis [7,8,19-21]. Additionally, elevated mouth-exhaled $\mathrm{NH}_{3}$ concentrations were detected in Helicobacter pylori infected patients after urea ingestion [22]. Furthermore, ammonia gas in the oral cavity has been proposed as a useful tool to assess halitosis [23]. In light of these potential clinical applications, we feel that it is essential to understand the mechanism of mouth-exhaled $\mathrm{NH}_{3}$ production in detail. To investigate the mouthexhaled $\mathrm{NH}_{3}$ production, we decided to measure ammonia simultaneously in oral fluid and mouthexhaled breath. Recently, we applied a similar methodology to investigate the oral production of hydrogen cyanide (HCN) [24]. We believe that by combining the breath measurements with the simultaneous oral fluid analysis, we can gain important insight into the production mechanisms of these orally generated volatile species.

It is known that urease can hydrolyse oral fluid urea into ammonia $[25,26]$. Urease is produced by oral bacteria, such as Streptococcus salivarius and Actinomyces naeslundii $[25,26]$. In addition, it has been shown that oral fluid $\mathrm{pH}$ affects the mouth-exhaled $\mathrm{NH}_{3}$ levels. Smith et al showed that rinsing the mouth with vinegar lowers the oral fluid $\mathrm{pH}$ value and the mouth-exhaled $\mathrm{NH}_{3}$ concentration [17]. On the other hand, a mouth wash with bicarbonate solution, which increases the oral fluid $\mathrm{pH}$ value, can increase the mouth-exhaled $\mathrm{NH}_{3}$ concentration [17]. Schmidt et al [9] and Solga et al [27] obtained similar results by showing that an acidic mouth rinse reduces the concentration of mouthexhaled $\mathrm{NH}_{3}$.

Based on the description above, we assume that there are three main factors affecting the mouthexhaled $\mathrm{NH}_{3}$ concentration: urea concentration, urease activity and oral fluid $\mathrm{pH}$. We hypothesize that the mechanism of the mouth-exhaled $\mathrm{NH}_{3}$ production in the oral cavity is as follows. Oral fluid urea is first hydrolysed to ammonia $\left(\mathrm{NH}_{4}{ }^{+}+\mathrm{NH}_{3}\right)$ by oral bacterial urease. The oral fluid ammonia and hydronium ion concentration determine the concentration of oral fluid $\mathrm{NH}_{3}$, which evaporates into gas phase and becomes mouth-exhaled $\mathrm{NH}_{3}$. To test this hypothesis, we measured the oral fluid $\mathrm{pH}$ value, the concentrations of oral fluid ammonia, urea and mouth-exhaled $\mathrm{NH}_{3}$ of one healthy subject under both fasting and normal conditions (an intra-subject test) as well as of 30 healthy subjects (an intersubject test) and investigated the respective correlations. In vitro and in vivo tests with an oral disinfectant were also employed to confirm the hypothesis.

\section{Material and Methods}

\subsection{Human subjects and sampling}

Thirty one volunteers participated in the study. A written consent was obtained from all participating individuals. Coordinating Ethics Committee of the Hospital District of Helsinki and Uusimaa approved the research. In the intra-subject, inter-subject and oral disinfectant in vivo tests, we measured mouth-exhaled $\mathrm{NH}_{3}$ levels on-line and took stimulated oral fluid samples from volunteers to measure the $\mathrm{pH}$ value, as well as ammonia and urea concentrations. A healthy female volunteer, aged 27, took part in the intra-subject test, including the fasting and diurnal tests. In the fasting test, the volunteer had breakfast two hours before the test. Afterwards eating and drinking was forbidden from 9:00 to 16:00. We measured 38 samples during two days. In the diurnal test, the diet of the volunteer was not controlled. We measured 24 samples in two days. Thirty healthy volunteers participated in the inter-subject test, each giving one sample. Sampling time was at least two hours after the last meal. Altogether 22 males and 8 females aged between 19 and 60 participated in this test. Samples were taken between 9:00 and 12:20.

Sampling time was at least two hours after the last meal in the comparison test of urea and ammonia concentrations in sublingual saliva and oral fluid. Three volunteers participated in this study: 
one male and two females aged between 21 and 37. The volunteers gave sublingual saliva and oral fluid samples at the same time. Samples were taken every $15 \mathrm{~min}$ from each volunteer. We obtained altogether 23 samples from three volunteers.

In the oral disinfectant in vitro test, we used Corsodyl as the disinfectant. It contains $0.2 \%$ of chlorhexidine digluconate, which destroys most of the oral bacteria and inhibits enzymatic activity [28]. In addition to the active ingredient, Corsodyl also contains ethanol, macrogolglycerol hydroxystearate, sorbitol, peppermint oil and purified water. We used two different spiked urea concentrations: $0.6 \mathrm{~mol} / \mathrm{L}$ and $2.5 \mathrm{~mol} / \mathrm{L}$. We prepared six tubes for this test (table 1). Solutions were mixed and kept at about $37^{\circ} \mathrm{C}$. After $45 \mathrm{~min}$, ammonia concentrations of the solutions were measured. The same protocol was repeated three times on two volunteers.

Table 1. The compositions of six test tubes in the disinfectant in vitro test.

\begin{tabular}{cccccc}
\hline Tube & Oral fluid $(\mu \mathrm{L})$ & Distilled $\mathrm{H}_{2} \mathrm{O}(\mu \mathrm{L})$ & Corsodyl $(\mu \mathrm{L})$ & $0.6 \mathrm{~mol} / \mathrm{L}$ Urea $(\mu \mathrm{L})$ & $2.5 \mathrm{~mol} / \mathrm{L}$ Urea $(\mu \mathrm{L})$ \\
\hline 1 & 300 & 300 & -- & -- & -- \\
2 & 300 & 300 & -- & 20 & -- \\
3 & 300 & --- & 300 & -- & -- \\
-34 & 300 & 300 & -- & -- & 20 \\
5 & 300 & -- & 300 & -- & 20 \\
\hline 6 & 300 & - & - & - \\
\hline
\end{tabular}

In the oral disinfectant in vivo test, three volunteers participated: two males and one female aged between 28 and 52. Each volunteer gave two samples before the oral disinfectant mouth rinse. Then the volunteers rinsed their mouths with $10 \mathrm{~mL}$ of Corsodyl for one minute and gave samples every 15 min. Each volunteer gave 10 samples.

\subsection{Measurement of mouth-exhaled $\mathrm{NH}_{3}$}

Mouth-exhaled $\mathrm{NH}_{3}$ was measured on-line by a commercial ammonia analyser (Picarro, G2103), based on cavity ring-down spectroscopy. The setup, performance of the analyser and breath gas sampling have been described in detail [9]. A metronome to control the breathing rate was not used in this study. Volunteers were asked to inhale normally through the nose, exhale through the mouth, and breathe to a mouth piece, which is connected to the analyser inlet tube. The mouth-exhaled $\mathrm{NH}_{3}$ concentration was recorded after three minutes of breathing.

\subsection{Stimulated oral fluid and sublingual saliva sampling}

Volunteers chewed a piece of a plastic paraffin film $(30 \mathrm{~mm} \times 30 \mathrm{~mm}$, Parafilm) for one minute. During chewing, components in the oral cavity are mixed within the oral fluid. Volunteers were asked to keep the oral fluid in the oral cavity without swallowing it. After one minute, all of the fluid was collected onto a plate. To sample the sublingual saliva, the volunteer touched the back of the upper front teeth with the apex of her tongue, tilted her head forward and let the freshly secreted saliva flow out directly from the sublingual area onto a plate.

\subsection{Measurement of oral fluid $\mathrm{pH}$}

Oral fluid $\mathrm{pH}$ was measured with a Horiba D-51 pH-meter using a flat tip ISFET electrode (Horiba, 0014-D00). The pH-meter was calibrated on every measurement day. After an oral fluid sample was collected onto a plate, the electrode was immediately dipped into the oral fluid sample and the $\mathrm{pH}$ value was measured.

\subsection{Determination of oral fluid and sublingual saliva ammonia}

The indophenol reaction was used to measure the oral fluid ammonia $\left(\mathrm{NH}_{4}{ }^{+}+\mathrm{NH}_{3}\right)$ concentration [29,30]. First, we prepared reagents $\mathrm{A}$ and B. Reagent A: $0.005 \mathrm{~g}$ of sodium nitroprusside $\left(\mathrm{Na}_{2}\left[\mathrm{Fe}(\mathrm{CN})_{5} \mathrm{NO}\right] \cdot 2 \mathrm{H}_{2} \mathrm{O}\right), 1.25 \mathrm{~g}$ of phenol and $1.0 \mathrm{~g}$ of $\mathrm{NaOH}$ were added into a $100 \mathrm{~mL}$ volumetric flask, and filled with distilled water to the mark. Reagent B: $1 \mathrm{~mL}$ of $14 \%$ sodium hypochlorite 
$(\mathrm{NaOCl})$ was added into a $100 \mathrm{~mL}$ volumetric flask, and filled with distilled water to the mark. $\mathrm{NH}_{4}{ }^{+}$ standard solutions $(25 \mu \mathrm{mol} / \mathrm{L}, 50 \mu \mathrm{mol} / \mathrm{L}, 100 \mu \mathrm{mol} / \mathrm{L}, 200 \mu \mathrm{mol} / \mathrm{L})$ were prepared from $\left(\mathrm{NH}_{4}\right)_{2} \mathrm{SO}_{4}$. To measure the oral fluid ammonia concentration, $20 \mu \mathrm{L}$ of oral fluid and $980 \mu \mathrm{L}$ of distilled water were added into a $15 \mathrm{~mL}$ glass tube. Then $2 \mathrm{~mL}$ of reagent $\mathrm{A}$ and $1 \mathrm{~mL}$ of reagent $\mathrm{B}$ were added into the tube and mixed well. The tube was incubated in a dark water bath at around $37{ }^{\circ} \mathrm{C}$ for 20 min. After the indophenol reaction, the solution was transferred from the tube to a cuvette. The absorption of the solution was measured (Ocean Optics, USB4000 and USB-ISS-UV/VIS) at $623 \mathrm{~nm}$. The same procedure was used to measure the ammonia concentration of sublingual saliva. For a standard curve, $1 \mathrm{~mL}$ of distilled water (blank solution) and $1 \mathrm{~mL}$ of each standard solution were added into separate tubes. Reagents A and B were added and the measurement steps were the same as just described.

Based on the oral fluid $\mathrm{pH}$ value and oral fluid ammonia $\left(\mathrm{NH}_{4}{ }^{+}+\mathrm{NH}_{3}\right)$ concentration, we calculated the oral fluid $\mathrm{NH}_{3}$ concentration with the Henderson-Hasselbalch equation [31]:

$$
\mathrm{pH}=\mathrm{pK}_{\mathrm{a}}+\log _{10}\left(\frac{\mathrm{cNH}_{3}}{\mathrm{cNH}_{4}^{+}}\right)
$$

where $\mathrm{cNH}_{3}$ and $\mathrm{cNH}_{4}{ }^{+}$are the concentrations of $\mathrm{NH}_{3}$ and $\mathrm{NH}_{4}{ }^{+}$, respectively, in oral fluid, and $\mathrm{pK}_{\mathrm{a}}$ is the acid dissociation coefficient of $\mathrm{NH}_{4}{ }^{+}$. At $37{ }^{\circ} \mathrm{C}$, the $\mathrm{pK}_{\mathrm{a}}$ value of $\mathrm{NH}_{4}{ }^{+}$in water is 8.890 [2]. We assume the same $\mathrm{pK}_{\mathrm{a}}$ value applies for saliva.

\subsection{Determination of oral fluid and sublingual saliva urea}

Ehrlich's reagent was used to measure the oral fluid urea concentration [32]. It was prepared by adding $1 \mathrm{~g}$ of $p$-dimethylaminobenzaldehyde and $1 \mathrm{~mL}$ of concentrated $\mathrm{H}_{2} \mathrm{SO}_{4}(98 \%)$ into a $25 \mathrm{~mL}$ volumetric flask, and filled with ethanol to the mark. Urea standard solutions $(0.5 \mathrm{mmol} / \mathrm{L}, 1.0$ $\mathrm{mmol} / \mathrm{L}, 1.5 \mathrm{mmol} / \mathrm{L}, 2.0 \mathrm{mmol} / \mathrm{L}$ ) were prepared for a urea standard curve. To determine the urea concentration in oral fluid, we added $100 \mu \mathrm{L}$ of oral fluid, $900 \mu \mathrm{L}$ of distilled water and $250 \mu \mathrm{L}$ of Ehrlich's reagent into a $1.5 \mathrm{~mL}$ microcentrifuge tube. The solution was centrifuged for $10 \mathrm{~min}$ at 6000 rpm (Hettich, EBA 3S). The clear solution was transferred into a cuvette. The absorption of the solution was measured at $422 \mathrm{~nm}$. Same procedure was used to measure the sublingual salivary urea concentration. For the urea standard curve, $1 \mathrm{~mL}$ of distilled water (blank solution) and $1 \mathrm{~mL}$ of each standard solution were added into tubes. Then, $250 \mu \mathrm{L}$ of Ehrlich's reagent was added. After $10 \mathrm{~min}$, the absorption of the mixed solution was measured.

\subsection{Repeatability test of oral fluid urea, ammonia, $\mathrm{pH}$ and mouth-exhaled $\mathrm{NH}_{3}$ measurement}

For the repeatability test of oral fluid urea and ammonia $\left(\mathrm{NH}_{4}{ }^{+}+\mathrm{NH}_{3}\right)$, both the urea and ammonia concentrations were measured from the same oral fluid sample ten times. For the $\mathrm{pH}$ measurement repeatability test, ten oral fluid samples were obtained five minutes apart. For the mouth-exhaled $\mathrm{NH}_{3}$, 12 breath samples were measured on-line five minutes apart.

\subsection{Statistical analysis}

Spearman's rank correlation test was used to analyze the correlations between mouth-exhaled $\mathrm{NH}_{3}$, the various oral fluid components (urea, ammonia and $\mathrm{pH}$ ), and volunteers' information (age and body mass index). In this test, the $p$ value refers to the probability of obtaining the observation results assuming the correlation coefficient $r_{s}$ is zero (null hypothesis).

The Mann-Whitney $U$ test was used to analyze differences in urea and ammonia concentration between sublingual saliva and oral fluid, as well as differences in mouth-exhaled $\mathrm{NH}_{3}$ between the male and female groups.

\section{Results}




\subsection{Repeatability test of oral fluid urea, ammonia, $\mathrm{pH}$ and mouth-exhaled $\mathrm{NH}_{3}$ measurement}

Table 1 shows the mean value, standard deviation (SD) and coefficient of variation (CV) of oral fluid urea, ammonia, $\mathrm{pH}$ and mouth-exhaled $\mathrm{NH}_{3}$ in the repeatability test. The $\mathrm{CV}$ value represents the error from measurement itself. The error in the urea measurement is higher than in the other experiments. After repeated tests, we have come to a conclusion that this variation is due to an interaction between the plastic pipette tip material and the Ehrlich's reagent. This leads to a variation in the amount of added reagent and subsequently results in a higher $\mathrm{CV}$ in the urea measurement.

Table 1. The repeatability test.

\begin{tabular}{ccccc}
\hline & Urea & Ammonia $\left(\mathrm{NH}_{4}{ }^{+}+\mathrm{NH}_{3}\right)$ & $\mathrm{pH}$ & Mouth-exhaled $\mathrm{NH}_{3}$ \\
\hline$N^{\mathrm{a}}$ & 10 & 10 & 10 & 12 \\
$\mathrm{Mean}$ & $8.3 \mathrm{mmol} / \mathrm{L}$ & $2.2 \mathrm{mmol} / \mathrm{L}$ & 7.06 & $820 \mathrm{ppb}$ \\
$\mathrm{SD}$ & $1.2 \mathrm{mmol} / \mathrm{L}$ & $0.2 \mathrm{mmol} / \mathrm{L}$ & 0.06 & $30 \mathrm{ppb}$ \\
$\mathrm{CV}^{\mathrm{b}}$ & 0.14 & 0.07 & 0.009 & 0.04 \\
\hline
\end{tabular}

${ }^{a}$ The quantity $N$ is the number of samples.

${ }^{\mathrm{b}}$ The coefficient of variation $(\mathrm{CV})$ is defined as the standard deviation divided by the mean value.

\subsection{The correlations in intra-subject and inter-subject tests}

Both in the intra-subject and inter-subject tests, we observed statistically significant correlations between oral fluid urea and ammonia $\left(\mathrm{NH}_{4}{ }^{+}+\mathrm{NH}_{3}\right)$ (table 2). This implies that oral fluid urea plays an important role in the oral fluid ammonia production. The strongest correlation was observed in the fasting test $\left(r_{s}=0.77, p<0.001\right)$ (figure 1$)$ of a single individual. There is a strong correlation between oral fluid $\mathrm{NH}_{3}$ and mouth-exhaled $\mathrm{NH}_{3}\left(r_{s}=0.81, p<0.001\right)$ in the inter-subject test (figure 2). The correlation in the intra-subject test is weaker (table 3). In addition, we observed a moderate correlation between oral fluid urea and mouth-exhaled $\mathrm{NH}_{3}\left(r_{s}=0.49, p=0.002\right)$ in the fasting test.

Table 2. Correlations between oral fluid urea and ammonia $\left(\mathrm{NH}_{4}{ }^{+}+\mathrm{NH}_{3}\right)$ in the intra-subject and intersubject tests.

\begin{tabular}{|c|c|c|c|c|c|c|c|}
\hline \multirow{2}{*}{\multicolumn{2}{|c|}{ Tests }} & \multicolumn{2}{|c|}{ Urea $\leftrightarrow \mathrm{NH}_{4}^{+}+\mathrm{NH}_{3}$} & \multicolumn{2}{|c|}{ Urea (mmol/L) } & \multicolumn{2}{|c|}{$\mathrm{NH}_{4}{ }^{+}+\mathrm{NH}_{3}(\mathrm{mmol} / \mathrm{L})$} \\
\hline & & $r_{s}$ & $p$ & Mean & $\mathrm{CV}^{\mathrm{a}}$ & Mean & $\mathrm{CV}^{\mathrm{a}}$ \\
\hline \multirow[t]{2}{*}{ Intra-subject } & Fasting $(n=38)$ & 0.77 & $<0.001$ & 5.3 & 0.64 & 3.3 & 0.21 \\
\hline & Diurnal $(n=24)$ & 0.51 & 0.01 & 5.6 & 0.29 & 2.3 & 0.26 \\
\hline \multicolumn{2}{|c|}{ Inter-subject $(n=30)$} & 0.46 & 0.01 & 6.9 & 0.43 & 4.7 & 0.41 \\
\hline
\end{tabular}

${ }^{a}$ The coefficient of variation (CV) is defined as the standard deviation divided by the mean value.

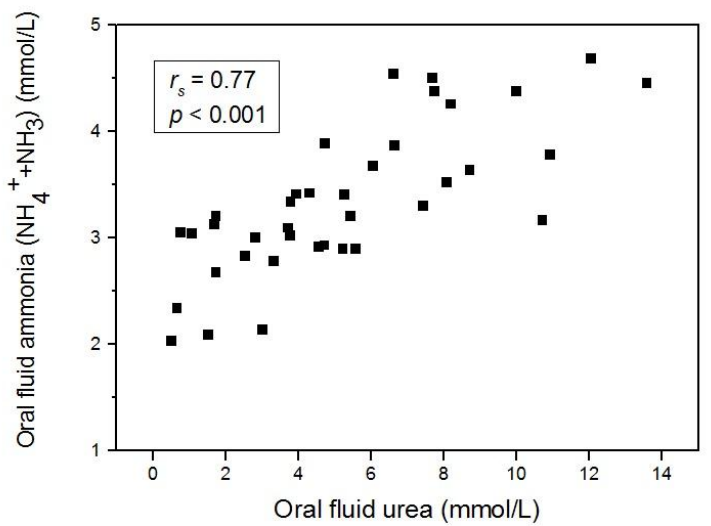

Figure 1. The correlation between oral fluid urea and ammonia $\left(\mathrm{NH}_{4}{ }^{+}+\mathrm{NH}_{3}\right)$ in the fasting test of a single individual. 
Table 3. Correlations between oral fluid $\mathrm{NH}_{3}$ and mouth-exhaled $\mathrm{NH}_{3}$ in the intra-subject and intersubject tests.

\begin{tabular}{|c|c|c|c|c|c|c|c|c|c|}
\hline \multirow{2}{*}{\multicolumn{2}{|c|}{ Tests }} & \multicolumn{2}{|c|}{$\begin{array}{l}\text { Oral fluid } \mathrm{NH}_{3} \leftrightarrow \text { Mouth- } \\
\text { exhaled } \mathrm{NH}_{3}\end{array}$} & \multicolumn{2}{|c|}{$\begin{array}{l}\text { Oral fluid } \mathrm{NH}_{3} \\
(\mu \mathrm{mol} / \mathrm{L})\end{array}$} & \multicolumn{2}{|c|}{$\begin{array}{l}\text { Mouth-exhaled } \mathrm{NH}_{3} \\
\text { (ppb) }\end{array}$} & \multicolumn{2}{|c|}{$\mathrm{pH}$} \\
\hline & & $r_{s}$ & $p$ & Mean & $\mathrm{CV}$ & Mean & $\mathrm{CV}$ & Mean & $\mathrm{CV}$ \\
\hline \multirow[t]{2}{*}{ Intra-subject } & Fasting $(n=38)$ & $0.19^{a}$ & $0.26^{a}$ & 33 & 0.28 & 630 & 0.16 & 6.89 & 0.014 \\
\hline & Diurnal $(n=24)$ & 0.53 & 0.008 & 33 & 0.24 & 360 & 0.24 & 6.98 & 0.018 \\
\hline \multicolumn{2}{|c|}{ Inter-subject $(n=30)$} & 0.81 & $<0.001$ & 42 & 0.68 & 630 & 0.49 & 6.79 & 0.038 \\
\hline
\end{tabular}

${ }^{\mathrm{a}}$ The one without statistically significant correlation is written in italics.

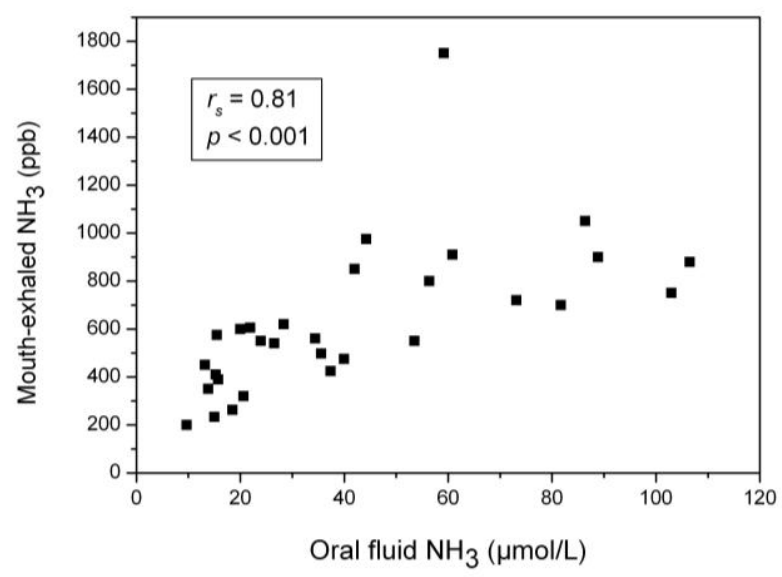

Figure 2. The correlation between oral fluid $\mathrm{NH}_{3}$ and mouth-exhaled $\mathrm{NH}_{3}$ in the inter-subject test.

Additionally, we found that volunteers' age was statistically significantly correlated to oral fluid $\mathrm{pH}\left(r_{s}=0.54, p=0.002\right)$ and negatively correlated to oral fluid urea $\left(r_{s}=-0.45, p=0.014\right)$. The mouthexhaled $\mathrm{NH}_{3}$ concentration of males $(690 \pm 310 \mathrm{ppb})$ was statistically significantly higher than that of females $(460 \pm 240 \mathrm{ppb})(p=0.04)$. The mean value of oral fluid $\mathrm{pH}$ and mouth-exhaled $\mathrm{NH}_{3}$ were 6.79 and $630 \mathrm{ppb}$, respectively, in the inter-subject test. These are close to our previous study, where the mean values of oral fluid $\mathrm{pH}$ and mouth-exhaled $\mathrm{NH}_{3}$ were 6.84 and $780 \mathrm{ppb}$, respectively [9].

\subsection{The urea and ammonia concentration in sublingual saliva and oral fluid}

There was no statistically significant difference of the urea concentration between sublingual saliva $(6.7 \pm 2.3 \mathrm{mmol} / \mathrm{L})$ and oral fluid $(6.5 \pm 1.0 \mathrm{mmol} / \mathrm{L})(p=0.68)$ (figure $3 \mathrm{a})$. However, the ammonia concentration in oral fluid $(2.9 \pm 1.9 \mathrm{mmol} / \mathrm{L})$ was significantly higher than in sublingual saliva $(0.4 \pm 0.2 \mathrm{mmol} / \mathrm{L})(p<0.001)$ (figure $3 \mathrm{~b})$.
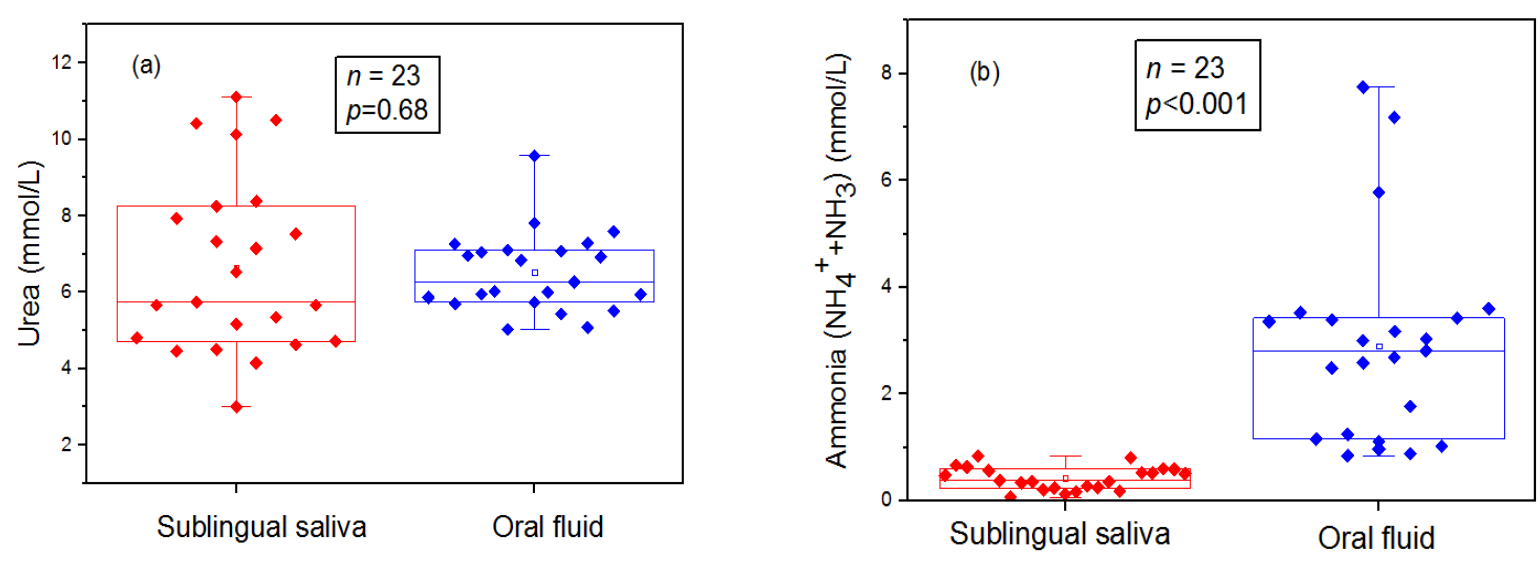
Figure 3. The urea concentration in sublingual saliva and oral fluid (a), the ammonia concentration in sublingual saliva and oral fluid (b) from three volunteers. The bottom and top of the box are the first and third quartiles, and the band inside the box is the median. The ends of the whiskers represent the minimum and maximum of all the data.

\subsection{Oral disinfectant in vitro and in vivo test}

In the oral disinfectant in vitro test, we added $20 \mu \mathrm{L}$ of $0.6 \mathrm{~mol} / \mathrm{L}$ and $2.5 \mathrm{~mol} / \mathrm{L}$ spiked urea into oral fluid samples. The final concentrations of the spiked urea in mixed solutions were $20 \mathrm{mmol} / \mathrm{L}$ and 80 $\mathrm{mmol} / \mathrm{L}$ respectively. The mean value of oral fluid urea in this study was $6 \mathrm{mmol} / \mathrm{L}$. An increase in the ammonia concentration was observed after spiking (figure 4). However, if an oral disinfectant was added at the same time, no increase in the ammonia concentration was observed. This result implies that without bacterial and enzymatic activity, urea cannot be hydrolysed into ammonia in oral fluid.

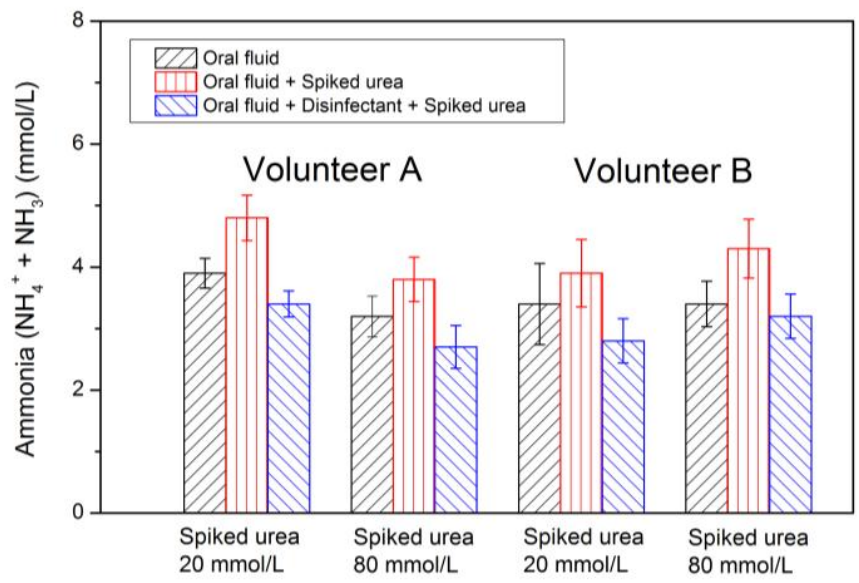

Figure 4. The mean values of ammonia $\left(\mathrm{NH}_{4}{ }^{+}+\mathrm{NH}_{3}\right)$ concentration from three repeat in vitro experiments. Error bars represent one standard deviation.

In the oral disinfectant in vivo test, a statistically significant correlation between oral fluid ammonia $\left(\mathrm{NH}_{4}{ }^{+}+\mathrm{NH}_{3}\right)$ and mouth-exhaled $\mathrm{NH}_{3}$ was observed only in one of the volunteers (A). However, there was a strong correlation between oral fluid $\mathrm{NH}_{3}$ and mouth-exhaled $\mathrm{NH}_{3}$ in the case of volunteer $\mathrm{A}$ $\left(r_{s}=0.90, p<0.001\right)$, and a moderate correlation in the case of volunteer $\mathrm{C}\left(r_{s}=0.64, p=0.048\right)$. Statistically significant correlation was not found for volunteer B $\left(r_{s}=-0.061, p=0.87\right)$. Results of the test are given in table 4.

Table 4. Correlations between oral fluid ammonia and mouth-exhaled $\mathrm{NH}_{3}$, and between oral fluid $\mathrm{NH}_{3}$ and mouth-exhaled $\mathrm{NH}_{3}$ in the oral disinfectant in vivo test.

\begin{tabular}{ccccccccccc}
\hline & $\begin{array}{c}\text { Oral fluid ammonia } \\
\left(\mathrm{NH}_{4}^{+}+\mathrm{NH}_{3}\right) \leftrightarrow \text { Mouth } \\
\text {-exhaled } \mathrm{NH}_{3}\end{array}$ & \multicolumn{2}{c}{$\begin{array}{c}\text { Oral fluid } \mathrm{NH}_{3} \leftrightarrow \text { Mouth- } \\
\text { exhaled } \mathrm{NH}_{3}\end{array}$} & \multicolumn{2}{c}{$\begin{array}{c}\text { Oral fluid } \mathrm{NH}_{3} \\
(\mu \text { mol/L) }\end{array}$} & \multicolumn{2}{c}{$\begin{array}{c}\text { Mouth-exhaled } \\
\mathrm{NH}_{3}(\mathrm{ppb})\end{array}$} & \multicolumn{2}{c}{$\mathrm{pH}$} & \\
& $r_{s}$ & $p$ & $r_{s}$ & $p$ & Mean & $\mathrm{CV}$ & Mean & $\mathrm{CV}$ & Mean & $\mathrm{CV}$ \\
\hline Volunteer A & 0.81 & 0.004 & 0.90 & $<0.001$ & 22 & 0.45 & 330 & 0.38 & 7.14 & 0.020 \\
Volunteer B & $-0.097^{a}$ & $0.79^{a}$ & $-0.061^{a}$ & $0.87^{a}$ & 53 & 0.28 & 259 & 0.17 & 7.09 & 0.006 \\
Volunteer C & $0.16^{a}$ & $0.65^{a}$ & 0.64 & 0.048 & 36 & 0.31 & 379 & 0.40 & 7.06 & 0.024 \\
\hline
\end{tabular}

${ }^{\mathrm{a}}$ The one without statistically significant correlation is written in italics.

\section{Discussion}


We observed statistically significant correlations between oral fluid urea and ammonia $\left(\mathrm{NH}_{4}{ }^{+}+\mathrm{NH}_{3}\right)$ in the intra-subject and inter-subject tests. Because only one subject participated in the intra-subject test, this might be considered as a potential weakness of our study. However, we also observed statistically significant correlation in the inter-subject test. Therefore, we believe that our results indicate that oral fluid urea is a dominant contributor to the oral fluid ammonia production. Furthermore, we find a moderate correlation between oral fluid urea and mouth-exhaled $\mathrm{NH}_{3}\left(r_{s}=0.49, p=0.002\right)$ in the fasting test. This implies that oral fluid urea is a significant source of mouth-exhaled $\mathrm{NH}_{3}$. The correlation between oral fluid urea and ammonia $\left(\mathrm{NH}_{4}{ }^{+}+\mathrm{NH}_{3}\right)$ in the fasting test $\left(r_{s}=0.77, p<0.001\right)$ is stronger than in the diurnal test $\left(r_{s}=0.51, p=0.01\right)$. The coefficient of variation $(\mathrm{CV})$ of urea concentration in the diurnal test $(\mathrm{CV}=0.29)$ is smaller than in the fasting test $(\mathrm{CV}=0.64)$, and is closer to the $\mathrm{CV}$ in the repeatability test $(\mathrm{CV}=0.14)$. This implies that the variation of urea concentration in the diurnal test is largely affected by the measurement error. Hence, the rank order of the urea concentrations in the diurnal test is more random, resulting in a weaker correlation obtained from Spearman's rank correlation test. In the fasting test, the higher $\mathrm{CV}$ of urea concentration implies a larger data range and less effect from the measurement error. Therefore, the rank order is less random, leading to a stronger correlation. The low $\mathrm{CV}$ of urea concentration in the diurnal test is probably due to the urea regulation system in the human body. However, during fasting, dehydration of the human body elevates the urea concentration [33], leading to a larger data range and higher CV. In the inter-subject test, the correlation is the weakest. This occurs because the variation in the oral conditions of 30 volunteers is larger than that of one volunteer in the intra-subject test. The ureolytic process varies among volunteers, leading to a weaker correlation between oral fluid urea and ammonia in the inter-subject test. In addition to ureolysis, arginolysis also produces ammonia in the oral cavity by catabolizing arginine [25]. However, the concentration of free form arginine in oral fluid is around $50 \mu \mathrm{mol} / \mathrm{L}$ [25], which is much less than the urea concentration in oral fluid measured in the inter-subject test (mean=6.9 $\mathrm{mmol} / \mathrm{L})$.

There was no significant difference in the urea concentration between oral fluid and sublingual saliva $(p=0.07)$, but the ammonia concentration in oral fluid was significantly higher than in sublingual saliva $(p<0.001)$. These results confirm that the ureolytic process takes place in the oral cavity. Since sublingual saliva is secreted freshly from sublingual glands, it contains less bacteria and enzymes than oral fluid. This results in a lower ammonia concentration in sublingual saliva. Previous studies have shown that oral fluid ammonia is generated through the hydrolysis of urea by urease [34,35], which is produced by oral bacteria $[25,26]$. Hence, urease activity affects the oral fluid ammonia concentrations. Similar conclusion can be drawn from the oral disinfectant in vitro test. We observed that spiking an oral fluid sample with urea increased the ammonia concentration. However, after adding a disinfectant, spiking with urea did not increase the ammonia concentration. This is because the bacterial and enzymatic activity is inhibited by the oral disinfectant. Without the bacterial and enzymatic activity, the spiked urea cannot be hydrolysed into ammonia.

Oral fluid ammonia further transfers to mouth-exhaled $\mathrm{NH}_{3}$. Depending on the oral fluid $\mathrm{pH}$ value, certain amount of ammonium ion $\left(\mathrm{NH}_{4}{ }^{+}\right)$turns to ammonia molecule $\left(\mathrm{NH}_{3}\right)$ in oral fluid and further evaporates into the gas phase. Based on the oral fluid ammonia concentrations and oral fluid $\mathrm{pH}$, we calculated the oral fluid $\mathrm{NH}_{3}$ concentrations. We found a strong correlation between oral fluid $\mathrm{NH}_{3}$ and mouth-exhaled $\mathrm{NH}_{3}$ in the inter-subject test $\left(r_{s}=0.81, p<0.001\right)$ and a moderate correlation in the diurnal test $\left(r_{s}=0.53, p=0.008\right)$. However, in the fasting test, there is no statistically significant correlation between them. Oral fluid $\mathrm{NH}_{3}$ is calculated from the Henderson-Hasselbalch equation using the value of oral fluid $\mathrm{pH}$. The $\mathrm{CV}$ of $\mathrm{pH}$ in the fasting test $(\mathrm{CV}=0.014)$ is close to that in the repeatability test $(\mathrm{CV}=0.009)$. This implies that the variation of oral fluid $\mathrm{pH}$ in the fasting test is affected to a large extent by the measurement error. The accuracy of $\mathrm{pH}$ measurement in oral fluid is influenced by the sampling and measurement techniques [36].

In the oral disinfectant in vivo test, Corsodyl was applied as the mouth rinse. As possible side effects, the manufacturer mentions swelling of the parotid glands, among other things. Although we cannot rule out the possibility that such side effects might affect the retrieved ammonia concentrations, 
we assume that the main effect of the mouth rinse is to destroy most of the oral bacteria and inhibit enzymatic activity. After the application of the mouth rinse, the influence of urease is thus minimized and oral fluid $\mathrm{pH}$ becomes the main factor affecting the mouth-exhaled $\mathrm{NH}_{3}$ concentration. In volunteer $\mathrm{A}$ and volunteer $\mathrm{C}$, we observed a stronger correlation between oral fluid $\mathrm{NH}_{3}$ and mouthexhaled $\mathrm{NH}_{3}$ than between oral fluid ammonia $\left(\mathrm{NH}_{4}{ }^{+}+\mathrm{NH}_{3}\right)$ and mouth-exhaled $\mathrm{NH}_{3}$. This implies that oral fluid $\mathrm{pH}$ has important effect on mouth-exhaled $\mathrm{NH}_{3}$ production. In addition, we notice that there is a stronger correlation in volunteer $\mathrm{A}\left(r_{s}=0.9, p<0.001\right)$ than in volunteer $\mathrm{C}\left(r_{s}=0.64, p=0.048\right)$, probably because $\mathrm{CV}$ of oral fluid $\mathrm{NH}_{3}$ in volunteer $\mathrm{A}(\mathrm{CV}=0.45)$ is higher than in volunteer $\mathrm{C}$ $(\mathrm{CV}=0.31)$. However, no statistically significant correlation was found in volunteer $\mathrm{B}$. This is most likely due to the low $\mathrm{CV}$ in oral fluid $\mathrm{pH}(\mathrm{CV}=0.006)$ and in mouth-exhaled $\mathrm{NH}_{3}(\mathrm{CV}=0.17)$.

Overall, the mouth-exhaled $\mathrm{NH}_{3}$ concentration in this study was affected by three primary factors: oral fluid urea concentration, bacterial urease activity and oral fluid $\mathrm{pH}$. Oral fluid urea is first hydrolysed to ammonia by bacterial urease. Oral fluid $\mathrm{NH}_{4}{ }^{+}$then transfers to $\mathrm{NH}_{3}$, depending on the oral fluid $\mathrm{pH}$ value. Finally, oral fluid $\mathrm{NH}_{3}$ evaporates into gas phase and turns to mouth-exhaled $\mathrm{NH}_{3}$.

In healthy people, since the urea concentration in body fluids is regulated to a certain level, the change of urea concentration is small. As a result, it is difficult to observe the correlation between body fluid urea and mouth-exhaled $\mathrm{NH}_{3}$. However, the situation is different in chronic kidney disease patients, because their body fluid urea concentration is abnormally high. Previous studies have shown that mouth-exhaled $\mathrm{NH}_{3}$ could be a potential marker to monitor the haemodialysis progress in chronic kidney disease patients [7,8,19-21]. Mouth-exhaled $\mathrm{NH}_{3}$ levels decrease during haemodialysis and there is a statistically significant correlation with blood urea. It was first shown by Kopstein et al that blood urea positively correlates to oral fluid ammonia [34]. Španěl et al showed that oral exposure to urea elevates the mouth-exhaled $\mathrm{NH}_{3}$ concentration, indicating that exogenous urea can influence the mouth-exhaled $\mathrm{NH}_{3}$ levels [37]. In our study, we demonstrated that endogenous urea (oral fluid urea) also influences the mouth-exhaled $\mathrm{NH}_{3}$ levels. Since blood urea is strongly correlated to oral fluid urea $[38,39]$, a decrease in blood urea leads to a decrease in oral fluid urea. The decrease in oral fluid urea results in a lowering of ammonia in oral fluid, followed by a subsequent decrease in mouth-exhaled $\mathrm{NH}_{3}$. In addition, Bots et al have shown that oral fluid $\mathrm{pH}$ decreases at the end of haemodialysis [40]. This will also have an effect of lowering the retrieved mouth exhaled $\mathrm{NH}_{3}$ levels by shifting the acidbase equilibrium in oral fluid. Endre et al have also shown that the decay of mouth-exhaled $\mathrm{NH}_{3}$ during dialysis does not necessarily follow a simple exponential behaviour and that there are distinct differences between individuals [20]. It is possible that some of their observations can be explained by individual differences in bacterial urease activity or changes in $\mathrm{pH}$ during dialysis. Simultaneous oral fluid and breath measurements should be conducted on haemodialysis patients to find out whether the changes in mouth-exhaled $\mathrm{NH}_{3}$ during haemodialysis can be explained by oral $\mathrm{NH}_{3}$ production from urea.

\section{Conclusion}

To our knowledge, this is the first study to explore the mechanism of the mouth-exhaled $\mathrm{NH}_{3}$ production by measuring ammonia simultaneously in oral fluid and mouth-exhaled breath. We show that mouth-exhaled $\mathrm{NH}_{3}$ is significantly affected by hydrolysis of urea in the oral cavity. We demonstrate that there are three main factors influencing mouth-exhaled $\mathrm{NH}_{3}$ levels: oral fluid urea concentration, bacterial urease activity and the oral fluid $\mathrm{pH}$ value. We conclude that oral fluid urea is hydrolysed to ammonia by oral bacterial urease. Depending on the oral fluid $\mathrm{pH}$, oral fluid total ammonia $\left(\mathrm{NH}_{4}{ }^{+} / \mathrm{NH}_{3}\right)$ converts to a certain amount of oral fluid $\mathrm{NH}_{3}$, which further evaporates into gas phase and turns to mouth-exhaled $\mathrm{NH}_{3}$.

\section{Acknowledgments}

We thank all study participants. We also thank Ms. Kajsa Roslund for help in testing the measurement techniques. The authors would like to gratefully acknowledge the University of Helsinki and the Academy of Finland for financial support. 


\section{References}

[1] Pocock S J, Ashby D, Shaper A G, Walker M and Broughton P M 1989 Diurnal variations in serum biochemical and haematological measurements J. Clin. Pathol. 42 172-9

[2] Lang W, Blöck T M and Zander R 1998 Solubility of NH3 and apparent pK of $\mathrm{NH}_{4}{ }^{+}$in human plasma, isotonic salt solutions and water at 37 degrees C Clin. Chim. Acta 273 43-58

[3] Pang P F, Gao X J, Xiao X L, Yang W Y, Cai Q Y and Yao S Z 2007 A wireless pH sensor using magnetoelasticity for measurement of body fluid acidity Anal. Sci. 23 463-7

[4] Adeva M M, Souto G, Blanco N and Donapetry C 2012 Ammonium metabolism in humans Metabolism: clinical and experimental 61 1495-511

[5] Huizenga J R, Vissink A, Kuipers E J and Gips C H 1999 Helicobacter pylori and ammonia concentrations of whole, parotid and submandibular/sublingual saliva Clin. Oral Invest. 3 84-7

[6] Czarnowski D, Górski J, Jóźwiuk J and Boroń-Kaczmarska A 1992 Plasma ammonia is the principal source of ammonia in sweat Eur. J. Appl. Physiol. 65 135-7

[7] Davies S, Španěl P and Smith D 1997 Quantitative analysis of ammonia on the breath of patients in end-stage renal failure Kidney Int. 52 223-8

[8] Neri G, Lacquaniti A, Rizzo G, Donato N, Latino M and Buemi M 2012 Real-time monitoring of breath ammonia during haemodialysis: use of ion mobility spectrometry (IMS) and cavity ring-down spectroscopy (CRDS) techniques Nephrol. Dial. transplant 0 1-8

[9] Schmidt F M, Vaittinen O, Metsälä M, Lehto M, Forsblom C, Groop P-H and Halonen L 2013 Ammonia in breath and emitted from skin J. Breath Res. 7017109

[10] Wang J, Zhang W, Li L and Yu Q 2011 Breath ammonia detection based on tunable fiber laser photoacoustic spectroscopy Appl. Phys. B 103 263-9

[11] Wakabayashi H, Kuwabara Y, Murata H, Kobashi K and Watanabe A 1997 Measurement of the expiratory ammonia concentration and its clinical significance Metab. Brain Dis. 12 161-9

[12] Shimamoto C, Hirata I and Katsu K 2000 Breath and blood ammonia in liver cirrhosis Hepatogastroenterol. 47 443-5

[13] Timmer B, Olthuis W and Berg A V D 2005 Ammonia sensors and their applications--a review Sensors Actuators 107 666-77

[14] Ishida H, Satou T, Tsuji K, Kawashima N, Takemura H, Kosaki Y, Shiratori S and Agishi T 2008 The breath ammonia measurement of the hemodialysis with a QCM-NH Bio-Med. Mater. Eng. 18 99-106

[15] DuBois S, Eng S, Bhattacharya R, Rulyak S, Hubbard T, Putnam D and Kearney D J 2005 Breath ammonia testing for diagnosis of hepatic encephalopathy Dig. Dis. Sci. 50 1780-4

[16] Wang T, Pysanenko A, Dryahina K, Španěl P and Smith D 2008 Analysis of breath, exhaled via the mouth and nose, and the air in the oral cavity J. Breath Res. 2037013

[17] Smith D, Wang T, Pysanenko A and Španěl P 2008 A selected ion flow tube mass spectrometry study of ammonia in mouth- and nose-exhaled breath and in the oral cavity Rapid Commun. Mass Spectrom. 22 783-9

[18] Hibbard T and Killard A J 2011 Breath ammonia levels in a normal human population study as determined by photoacoustic laser spectroscopy J. Breath Res. 5037101

[19] Narasimhan L R, Goodman W and Patel C K N 2001 Correlation of breath ammonia with blood urea nitrogen and creatinine during hemodialysis Proc. Natl. Acad. Sci. U.S.A. 98 4617-21

[20] Endre Z H, Pickering J W, Storer M K, Hu W, Moorhead K T, Allardyce R, McGregor D O and Scotter J M 2011 Breath ammonia and trimethylamine allow real-time monitoring of haemodialysis efficacy Physiol. Meas. 32 115-30

[21] Popa C, Dutu D C A, Cernat R, Matei C, Bratu A T, Banita S and Dumitras D C 2011 Ethylene and ammonia traces measurements from the patients' breath with renal failure via LPAS method Appl. Phys. B 105 669-74

[22] Kearney D J, Hubbard T and Putnam D 2002 Breath ammonia measurement in Helicobacter pylori infection Digest. Dis. Sci. 47 2523-30 
[23] Amano A, Yoshida Y, Oho T and Koga T 2002 Monitoring ammonia to assess halitosis Oral Surg Oral Med Oral Pathol Oral Radiol Endod 94 692-6

[24] Chen W, Metsälä M, Vaittinen O and Halonen L 2014 Hydrogen cyanide in the headspace of oral fluid and in mouth-exhlaed breath J. Breath Res. 8027108

[25] Burne R A and Marquis R E 2000 Alkali production by oral bacteria and protection against dental caries FEMS Microbiol. Lett. 193 1-6

[26] Morou-Bermudez E, Elias-Boneta A, Billings R J, Burne R A, Garcia-Rivas V, BrignoniNazario V and Suarez-Perez E 2011 Urease activity in dental plaque and saliva of children during a three-year study period and its relationship with other caries risk factors Arch. Oral Biol. 56 1282-9

[27] Solga S F, Mudalel M, Spacek L A, Lewicki R, Tittel F, Loccioni C, Russo A and Risby T H 2013 Factors influencing breath ammonia determination J. Breath Res. 7037101

[28] Cousido M C, Carmona I T, Garcia-Caballero L, Limeres J, Alvares M. and Diz P 2010 In vivo substantivity of $0.12 \%$ and $0.2 \%$ chlorhexidine mouthrinses on salivary bacteria Clin. Oral Invest. 14 397-402

[29] Chaney A L and Marbach E P 1962 Modified reagents for determination of urea and ammonia Clin. Chem. 8 130-2

[30] Huizenga J R and Gips C H 1982 Determination of Ammonia in Saliva Using Indophenol, an Ammonium Electrode and an Enzymatic Method: A Comparative Investigation J. Clin. Chem. Clin. Biochem. 20 571-4

[31] Zumdahl S S and Zumdahl S A 2003 Chemistry (Boston: Houghton Mifflin) p 722

[32] Knorst M T, Neubert R and Wohlrab W 1997 Analytical methods for measuring urea in pharmaceutical formulations J. Pharm. Biomed. Anal. 15 1627-32

[33] Black D A K, McCance R A and Young W F 1944 A study of dehydration by means of balance experiments J. Physiol. 102 406-14

[34] Kopstein J and Wrong O M 1977 The origin and fate of salivary urea and ammonia in man Clinical science and molecular medicine $\mathbf{5 2}$ 9-17

[35] Sissons C H, Cutress T W and Pearce E I 1985 Kinetics and product stoichiometry of ureolysis by human salivary bacteria and artificial mouth plaques Arch. Oral Biol. 30 781-90

[36] Schipper R G, Silletti E and Vingerhoeds M H 2007 Saliva as research material: Biochemical, physicochemical and practical aspects Arch. Oral Biol. 52 1114-35

[37] Španěl P, Turner C, Wang T, Bloor R and Smith D 2006 Generation of volatile compounds on mouth exposure to urea and sucrose: implications for exhaled breath analysis Physiol. Meas. 27 7-17

[38] Cardoso E M L, Arregger A L, Tumilasci O R, Elbert A and Contreras L N 2009 Assessment of salivary urea as a less invasive alternative to serum determinations Scand. J. Clin. Lab. Inv. $69330-4$

[39] Peng C, Xia Y, Wu Y, Zhou Z, Cheng P and Xiao P 2013 Influencing factors for saliva urea and its application in chronic kidney disease Clin. Biochem. 46 275-7

[40] Bots C Pet al 2007 Acute effects of hemodialysis on salivary flow rate and composition Clin. Nephrol. 67 25-31 